\title{
Cimetidine treatment for the prevention of recurrence of duodenal ulcer: an international collaborative study
}

\author{
W. L. BURLAND \\ M.B., Ch.B., D.C.H., Dip. Pharm. Med. (R.C.P. U.K.) \\ B. W. HAWKINS \\ B.Sc. \\ J. BERESFORD \\ B.Sc., M.B.C.S.
} Departments of Clinical Research and Mathematical Services, The Research Institute,
Smith Kline and French Laboratories, Welwyn Garden City, Hertfordshire

\begin{abstract}
Summary
Comparison of cimetidine and placebo in the prevention of recurrence of ulceration was carried out in the study of 696 patients with recently healed duodenal ulcers. Treatment with cimetidine $400 \mathrm{mg}$ at bedtime or twice daily for up to 12 months very significantly reduced recurrence of symptomatic ulceration. Asymptomatic ulceration occurred in treated and untreated patients but was found significantly less often in cimetidine-treated patients. There were no serious untoward effects of cimetidine treatment. Only 3 patients $(0.8 \%)$ were withdrawn for possible drugrelated reasons. Evidence from other studies suggests that the natural history of duodenal ulcer remains unaltered when cimetidine treatment is stopped after one year. Investigations have been planned to study the efficacy and safety of longer periods of treatment.
\end{abstract}

\section{Introduction}

Duodenal ulcer is a chronic relapsing disease with low mortality but relatively high morbidity due principally to recurrent symptoms and re-ulceration.

The introduction of powerful inhibitors of gastric acid secretion, the histamine $\mathbf{H}_{2}$ antagonists, has brought about a change in the medical treatment of duodenal ulcer. Cimetidine treatment is associated with rapid symptomatic relief and ulcer healing demonstrated at endoscopy in more than $80 \%$ of patients after 4 to 6 weeks (Bodemar and Walan, 1976; Gray et al., 1977; Hetzel et al., 1978). Previously, no medical treatment adequately prevented the recurrence of duodenal ulcer and surgery has become the treatment of choice for intractable ulcer. Surgical treatment is not without mortality or morbidity, including a low incidence of recurrent ulceration. Since the early reports of successful treatment of duodenal ulcer with cimetidine, interest has grown in the possibility of maintaining patients symptom- and ulcer-free by continuing treatment with cimetidine after ulcer healing has occurred. Interim results have been reported from an international collaborative controlled study which indicated that cimetidine at a reduced dose $(400 \mathrm{mg}$ at bedtime or $400 \mathrm{mg}$ twice daily) could significantly reduce the recurrence of ulceration in duodenal ulcer disease (Burland et al., 1978). The final results for that population of patients, all of whom have now completed treatment and who suffered a recurrence of duodenal ulceration or otherwise discontinued treatment, are reported here.

\section{Methods}

A double-blind controlled study was set up (Table 1) for 696 patients whose duodenal ulcer was found to be healed at endoscopy after treatment with cimetidine, placebo or other treatment. They were randomly allocated to treatment with cimetidine $400 \mathrm{mg}$ morning and evening or cimetidine $400 \mathrm{mg}$ at bedtime or to corresponding placebo treatment within 7 days of endoscopy.

Treatment was intended to last 12 months in all but one of the individual studies where 54 patients were allocated to cimetidine twice daily and 55 to placebo for 6 months.

The patients understood the nature of the trial and consented to take part. They were reviewed monthly as out-patients. The return of persistent ulcer symptoms was taken as indication for re-examination by endoscopy. A proportion of asymptomatic patients were also examined by endoscopy approximately 6 or 12 months after starting treatment. Patients were withdrawn as treatment failures if re-ulceration was confirmed.

\section{Statistical methods}

Data were compared for symptomatic recurrence of duodenal ulcer using the generalized Wilcoxon test for comparing arbitrarily single-censored 
TABle 1. Study population

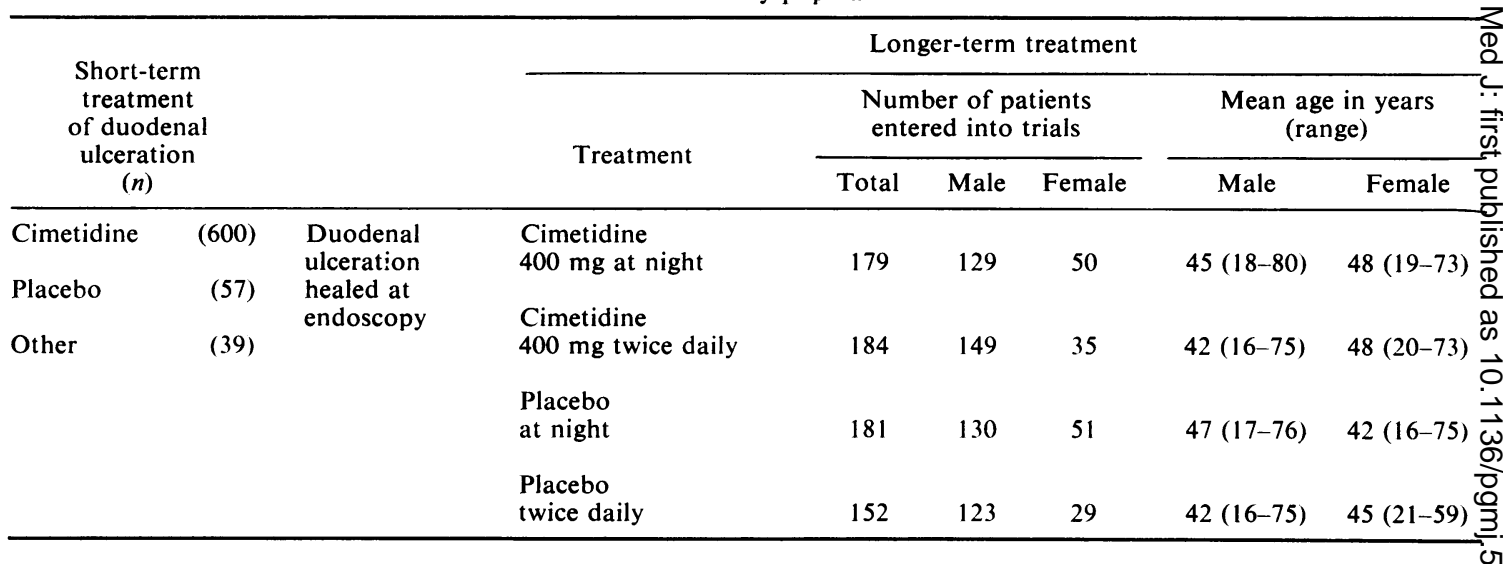

samples (Gehan, 1965). The $\chi^{2}$ test was used to compare groups for the occurrence of asymptomatic re-ulceration.

\section{Results}

\section{Symptomatic re-ulceration}

Thirty-one patients $(17 \cdot 3 \%)$ who received cimetidine $400 \mathrm{mg}$ at bedtime and $28(15 \cdot 2 \%)$ who received a twice daily dose had a symptomatic recurrence of duodenal ulceration during treatment (Table 2). The difference in recurrences was not significant. In contrast, $178(53.5 \%)$ of the patients who received placebo had a symptomatic recurrence of ulceration. Re-ulceration occurred very significantly more in placebo treated patients $(P<0.001)$.

Since patients were treated for varying periods before re-ulceration occurred or treatment was completed, these results can be expressed as the number of recurrent ulcers for every 100 completed months of treatment in each treatment group (Table 2 ). The results for the cimetidine-treated groups are similar, whereas the much higher recurrence rate amongst placebo-treated patients is confirmed.

\section{Asymptomatic re-ulceration}

Two hundred and seventy-seven patients who were symptom-free were examined by endoscopy during treatment (Table 2). Eight $(9 \cdot 6 \%$ of those examined in the treatment group) who were receiving cimeti dine $400 \mathrm{mg}$ at bedtime, $17(16.3 \%)$ receiving cimetidine $400 \mathrm{mg}$ twice daily and $24(26.7 \%)$ onw placebo were found to have a duodenal ulcero Asymptomatic ulceration was found significantly more often in placebo-treated patients than in cimetidine-treated patients $(P<0.01)$.

\section{Withdrawal from treatment}

Because of re-ulceration, 286 patients were w drawn from treatment, 154 failed to treatment by default, 245 completed their alloca treatment and 11 were withdrawn because of untoward events.

Nine patients withdrawn because of untowarc events were receiving cimetidine $400 \mathrm{mg}$ at bedtime and 2 receiving placebo. Four of the former died, 20 from myocardial infarction, one from a rupturec aortic aneurysm and one from septic shock. Bott placebo-treated patients suffered a myocardialinfarction and one died. One cimetidine-treated patient developed heart failure and another tachy cardia after myocardial infarction. Three cimetidine 3 treated patients $(0.8 \%$ of those receiving cimetidine were withdrawn for reasons which may have been treatment-related, one developed impotence, ones tremor, vertigo and headache and the third hadP elevated serum transaminases.

TABLE 2. Outcome of treatment

\begin{tabular}{|c|c|c|c|c|c|}
\hline \multirow[b]{2}{*}{ Treatment $(n)$} & & \multicolumn{2}{|c|}{ Symptomatic re-ulceration } & \multicolumn{2}{|c|}{ Asymptomatic re-ulceration } \\
\hline & & Number $(\%)$ & $\begin{array}{c}\text { Number of recurrences/ } \\
\text { '100 patient months' } \\
\text { treatment }\end{array}$ & $\begin{array}{c}\text { Number of } \\
\text { patients examined }\end{array}$ & $\begin{array}{l}\text { Number }(\%) \text { with } \\
\text { re-ulceration }\end{array}$ \\
\hline $\begin{array}{l}\text { Cimetidine } 400 \mathrm{mg} \text { at night } \\
\text { Cimetidine } 400 \mathrm{mg} \text { twice daily } \\
\text { Placebo }\end{array}$ & $\begin{array}{l}(179) \\
(184) \\
(333)\end{array}$ & $\begin{array}{r}31(17 \cdot 3) \\
28(15 \cdot 2) \\
178(53 \cdot 5)\end{array}$ & $\begin{array}{l}2 \cdot 0 \\
1 \cdot 8 \\
9 \cdot 5\end{array}$ & $\begin{array}{r}83 \\
104 \\
90\end{array}$ & $\begin{array}{r}8(9 \cdot 6) \\
17(16 \cdot 3) \\
24(26 \cdot 7)\end{array}$ \\
\hline
\end{tabular}


Patients who were lost to follow-up have been included in the analysis of data up to the time of their last out-patient review (at which time they were still symptom-free). Although the loss of these patients gradually reduced the population available for study, $52(34 \%)$ of them were lost only in the last 2 months of the 12-month treatment period. The number of patients available for review each month of treatment does enable the probability of symptomatic ulcer recurrence and the time of recurrence to be estimated for the whole population (Fig. 1).

\section{Influence of previous treatment}

The recurrence of ulcer according to previous treatment is shown in Table 3. There was a symptomatic recurrence of ulceration in $63 \%$ of patients who received cimetidine to heal their ulcer and were treated with placebo afterwards, compared with
$47 \%$ of the smaller number of patients whose ulcer healed on placebo and who were then maintained on placebo. However, the difference is not statistically significant and the latter group had a higher (though non-significant) incidence of asymptomatic ulcer $(38 \%$ against $22 \%)$.

\section{Discussion}

These data clearly confirm conclusions drawn from the interim report that treatment with cimetidine $400 \mathrm{mg}$ at bedtime or $400 \mathrm{mg}$ twice daily significantly reduces the occurrence of symptomatic re-ulceration in patients with duodenal ulcer. This finding has been supported by Gray et al. (1978), Bodemar and Walan (1978), Bardhan et al. (1979), Gudmand-Høyer et al. (1978), and by Hetzel et al. (1978) in individual studies. The results also confirm that asymptomatic ulceration is a feature of chronic

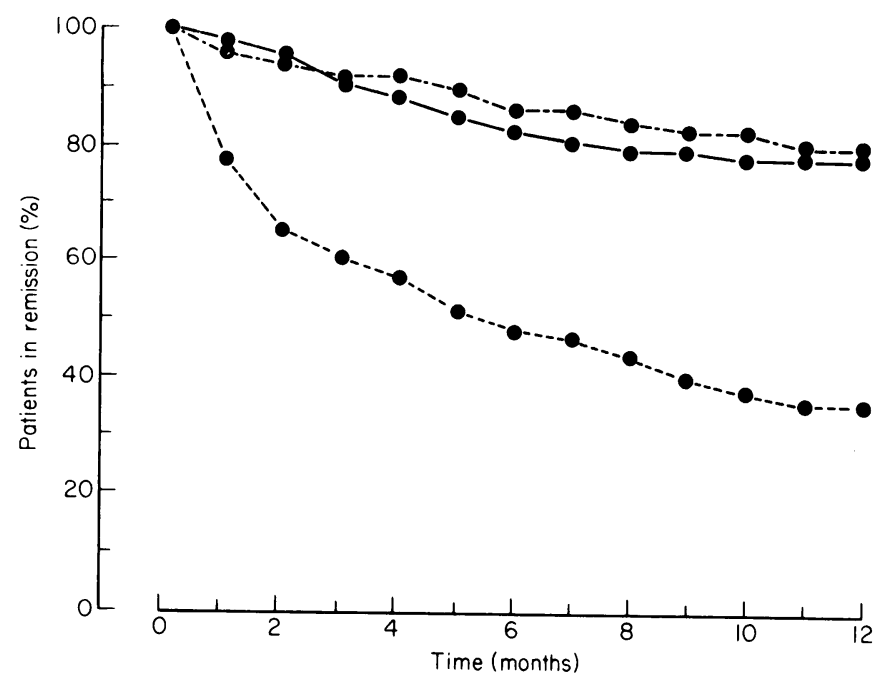

FIG. 1. Percentage of patients in clinical remission throughout treatment. (The expected remission periods for patients lost to follow-up are included.).--0 , Cimetidine $400 \mathrm{mg}$ twice daily (184); cimetidine $400 \mathrm{mg}$ at night (179); ---0 , placebo (333).

TABLE 3. Outcome of treatment according to previous treatment

\begin{tabular}{|c|c|c|c|c|c|}
\hline \multirow{2}{*}{$\begin{array}{l}\text { Short-term treatment } \\
\text { when ulcer healing } \\
\text { occurred }\end{array}$} & \multirow{2}{*}{\multicolumn{2}{|c|}{$\begin{array}{l}\text { Longer-term treatment } \\
\qquad(n)\end{array}$}} & \multirow[b]{2}{*}{$\begin{array}{c}\text { Symptomatic } \\
\text { re-ulceration }(\%)\end{array}$} & \multicolumn{2}{|c|}{ Asymptomatic patients } \\
\hline & & & & $\begin{array}{l}\text { Number } \\
\text { examined }\end{array}$ & $\begin{array}{c}\text { Re-ulceration } \\
(\%)\end{array}$ \\
\hline Cimetidine & $\begin{array}{l}\text { Placebo } \\
\text { Cimetidine } 400 \mathrm{mg} \text { at night } \\
\text { Cimetidine } 400 \mathrm{mg} \text { twice daily }\end{array}$ & $\begin{array}{l}(290) \\
(161) \\
(149)\end{array}$ & $\left.\begin{array}{r}184(63) \\
28(17) \\
27(18)\end{array}\right\} 55(18)$ & $\begin{array}{l}77 \\
77 \\
84\end{array}$ & $\begin{array}{r}17(22) \\
7 \quad(9) \\
11(13)\end{array}$ \\
\hline Placebo & $\begin{array}{l}\text { Cimetidine } 400 \mathrm{mg} \text { at night } \\
\text { Cimetidine } 400 \mathrm{mg} \text { twice daily } \\
\text { Placebo }\end{array}$ & $\begin{array}{r}(18) \\
(9) \\
(30)\end{array}$ & $\begin{array}{r}\left.\begin{array}{l}3(17) \\
1(11) \\
14(47)\end{array}\right\} 4(15) \\
4\end{array}$ & $\begin{array}{r}6 \\
5 \\
13\end{array}$ & $\begin{array}{l}2(33) \\
1(20) \\
5(38)\end{array}$ \\
\hline
\end{tabular}

Thirty-nine patients who received other short-term treatment before being allocated to longer-term treatment with cimetidine or placebo, are excluded from this table. 
duodenal ulcer disease but that it is found less often during cimetidine treatment. There was no greater incidence of asymptomatic ulcer after a short course of cimetidine than occurs in other groups of patients, and initial treatment given to heal duodenal ulcer had no significant influence on later recurrence of ulceration.

The data reported here, therefore, support the use of cimetidine $400 \mathrm{mg}$ once or twice daily for up to 12 months to prevent recurrence of ulceration in patients with duodenal ulcer who have responded successfully to a short course of treatment and who are considered likely to suffer from frequent relapse.

One of the many problems in determining the benefits of longer-term treatment for duodenal ulcer is that the natural history of the disease and its influence on the outcome of treatment is difficult to predict. However, Gudmand-Høyer et al. (1978), Dronfield et al. (1979), and Hansky et al. (1979) have provided evidence that the rate of recurrence of duodenal ulcer in the 6 -month period after 6 or 12 months' treatment with reduced doses of cimetidine is similar to that seen after a short course of treatment.

There are, therefore, further questions to be answered. Can treatment for longer than 12 months be as successful in preventing recurrence as is $\mathbf{1 2}$ months' treatment? For how long can treatment be continued in asymptomatic patients, and can treatment for several years alter the natural history of the disease so that further recurrences are prevented or markedly delayed once treatment is stopped? The 'default' rate in this study may be an indication that asymptomatic patients are not likely to continue treatment for long periods or attend a clinic regularly and in particular are not prepared to undergo frequent endoscopy. Finally, how safe is long-term cimetidine treatment?

These questions can only be answered by the conduct of more carefully planned and controlled clinical studies, some of which are already under way. The safety of these lower doses of cimetidine for long-term administration in duodenal ulcer was reviewed by Burland (1978) who reported no effects during 12 months' treatment different from those described in short-term studies. Further data are required to substantiate this and to extend the experience beyond 12 months' treatment. However, the actions and properties of cimetidine are well documented. This, and the fact that a reduction to $400 \mathrm{mg}$ from the therapeutic dose and in the frequency of administration is sufficient to maintain duodenal ulcer patients in remission, is reassuring.

\section{Acknowledgments}

We gratefully acknowledge the clinical investigators whọ have given us permission to publish data from their patient? and thank them and their clinical and laboratory colleagues. for their participation in the study. They are (U.K. unles otherwise stated): J. P. Bader (France), K. D. Bardhan? A. Berstad (Norway), G. Bianchi-Porro (Italy), M. vā Blankenstein (Holland), A. L. Blum (Switzerland), H. LDuthie, G. Gillespie, J. Kreuning (Holland), R. Lamber屯 (France), M. J. S. Langman, W. Larkworthy, C. F. McCarth (Eire), R. Mekel and M. G. Moshal (S. Africa), P. M. Smithฉ B. J. Smits, G. Strohmeyer (West Germany), C. Wص Venables, A. Walan (Sweden), D. G. Weir and M. Wheltorn' (Eire), J. H. Wyllie. We also wish to thank Dr P. Lance and Mr C. Wastell and Churchill Livingstone for permission to reproduce Table 1.

\section{References}

Bardhan, K.D., SAul, D.M., Edwards, J.L., SMITH, P.M. HAGGIE, S.J., Wyllie, J.H., DuthIE, H.L., \& FuSSEY, I.Vড় (1979) Double-blind comparison of cimetidine and placebo in the maintenance of healing of chronic duodenal ulcera tion. Gut, 20, 158.

BoDemar, G. \& Walan, A. (1976) Cimetidine in the treat ment of active duodenal and prepyloric ulcers. Lancet, $\mathrm{ii}_{2}-$ 161.

Bodemar, G. \& Walan, A. (1978) Maintenance treatment of recurrent peptic ulcer by cimetidine. Lancet, i, 403.

BURLAND, W.L. (1978) Evidence for the safety of cimetidinein the treatment of peptic ulcer disease. In: Proceeding.0 050 the International Symposium on Cimetidine, Göttingen 19? (Ed. by Creutzfeldt, W.), p. 238, Excerpta Medisa.0 Amsterdam.

Burland, W.L., Hawkins, B.W., Horton, R.J. $\stackrel{\text { ? }}{\&}$ BERESFORD, J. (1978) The longer-term treatment of duo denal ulcer with cimetidine. In: Cimetidine, Westminstern Hospital Symposium. (Ed. by Wastell, C. \& Lance, P.),p龠 66. Churchill Livingstone, London and Edinburgh.

Dronfield, M.W., Batchelor, A.J., LARKWORTHY, W. $\& \overrightarrow{\tilde{\sigma}}$ LANGMAN, M.J.S. (1979) Effect of maintenance cimetidine-3 treatment in duodenal ulcer and the eventual outcome after cessation of treatment. Gut, 20, 526.

GeHAN, E.A. (1965) The generalized Wilcoxon test for comparing arbitrarily single-censored samples. Biometrika,o 52, 203.

Gray, G.R., MacKenzie, I., Smith, I.S., Crean, G.P. \&ं GILlESPIE, G. (1977) Oral cimetidine in severe duodenaB ulceration. A double-blind controlled trial. Lancet, i, 4.

Gray, G.R., SMITH, I.S., MACKenZIE, I. \& GILlesPIE, G.O (1978) Long-term cimetidine in the management of severe duodenal ulcer dyspepsia. Gastroenterology, 74, 397.

Gudmand-Høyer, E., JenSEN, K.B., KRAG, E., RASKMADSEN, J. \& RAHBEK, I. (1978) Prophylactic effect of cimetidine in duodenal ulcer disease. British Medical Journal, 1, 1095.

Hansky, J., Korman, M.G., Hetzel, D.J. \& Shearman, D.J.C. (1979) Relapse rate after cessation of 12 months' $N$ cimetidine in duodenal ulcer. Gastroenterology, 76, 1151. 요

Hetzel, D.J., Shearman, D.J.C., Hansky, J., Korman, M.G., HeCKer, R., JACKSON, R., GABb, B.W. \& SheERS, R (1978) Maintenance of remission of duodenal ulcer by cimetidine: a double-blind controlled trial. Gut, 19, 442. 